\title{
QUOTES BUDI UTOMO SEBAGAI SARANA PENGUAT KESADARAN NASIONAL
}

\author{
Brigida Intan Printina ${ }^{1}$ \\ Dosen Universitas Sanata Dharma Yogyakarta \\ Jl. Affandi, Mrican, Caturtunggal, Depok, Sleman, DIY 55281
}

\begin{abstract}
ABSTRAK
Artikel ini bertujuan untuk menggambarkan Quotes Budi Utomo Berbasis Aplikasi Canva untuk Penguat Kesadaran Nasional. Agar perjuangan gerakan Budi Utomo dimaknai secara mendalam oleh generasi maka media visual grafis dipilih untuk menguatkan kesadaran nasional generasi. Hal ini selaras dengan prinsip dasar pergerakan Budi Utomo yaitu keutamaan pikiran atau budi dalam hal pendidikan. Metode penelitian dalam artikel ini ialah deskriptif kualitatif. Hasil penulisan mendeskripsikan proses dan hasil pengggunaan media visual grafis yang memotret pergerakan Budi Utomo dengan tujuan memperkuat kesadaran nasional para pemuda Indonesia sehingga mampu mengintegrasikan perjuangan masa lalu sebagai suatu modal "mengulang kembali kejayaan masa lalu" lewat pendidikan. Harapannya dengan artikel ini para pemerhati sejarah mampu mengimplementasikan pembelajaran sejarah dengan mudah dan dapat menyesuaikan perkembangan teknologi, namun tanpa kehilangan identitas sebagai bangsa yang berbudaya.
\end{abstract}

Kata Kunci: Quotes, Budi Utomo, Sarana Penguat Kesadaran Nasional

\begin{abstract}
This article aims to describe the Budi Utomo Quotes Based on Canva Applications for National Awareness Strengthens. In order for the struggle of the Budi Utomo movement to be interpreted in depth by generations, the visual graphic media was chosen to strengthen the national awareness of the generation. This is in line with the basic principles of Budi Utomo's movement, namely the primacy of mind or mind in terms of education. The research method in this article is qualitative descriptive. The writing results describe the process and results of the use of visual graphic media that photographed Budi Utomo's movement with the aim of strengthening the national awareness of Indonesian youth so as to be able to integrate past struggles as a capital "repeating the glory of the past" through education. The hope with this article is that observers of history are able to implement historical learning easily and can adjust technological developments, but without losing their identity as a cultured nation.
\end{abstract}

\section{Keywords: Quotes, Budi Utomo, National Awareness Strengthening Facility}

\section{PENDAHULUAN}

Penderitaan yang dialami oleh kaum pribumi akibat praktek kolonialismeimperialisme oleh bangsa Barat sudah tak terperikan lagi. Pribumi yang merasa terjajah secara lahir-batin, ingin bersegera menyudahi nasib yang mereka alami, yaitu dengan bereaksi melawan penjajah. Berbagai perlawanan bersenjata di berbagai pelosok Nusantara, seperti Perang Diponegoro, Perang Padri, Perang Puputan, dan lain sebagainya, dilancarkan dalam rangka mengusir penjajah. Namun, rupanya, perlawanan menggunakan otot tidak begitu

\footnotetext{
${ }^{1}$ Penulis Koresponden

E-mail address: intanbrigida@usd.ac.id doi: $10.25157 /$ ja.v6i1.2043
}

membuahkan hasil; walau dari segi kuantitas memang massa dari pihak pribumi yang dikerahkan di medan perang cukup banyak, namun dalam segi teknologi persejataan masih kalah jauh apabila dibandingkan dengan bangsa Barat. Hal tersebut yang membuat kaum pribumi berubah haluan, yang semula mengandalkan kekuatan otot diganti dengan kekuatan otak; yang semula terlihat sangat non-kooperatif menjadi (pura-pura) kooperatif.

Kebangkitan nasional adalah masa dimana bangkitnya rasa dan semangat persatuan, kesatuan dan nasionalisme serta kesadaran untuk memperjuangkan kemerdekaan republik

Copyright@2019 Jurnal Artefak e-ISSN: 2580-0027 
Indonesia. Masa ini ditandai dengan lahirnya Budi Utomo pada tanggal 20 Mei 1908 sebagai organisasi pelajar guna memajukan kepentingan-kepentingan priyayi rendah, dimana jangkauan geraknya terbatas pada penduduk Pulau Jawa dan Madura. (M.C. Ricklefs, 1998:249).

\section{METODE PENELITIAN}

Metode yang digunakan ialah deskriptif kualitatif untuk menggambarkan Quotes Budi Utomo Berbasis Aplikasi Canva untuk Penguat Kesadaran Nasional.

\section{HASIL PENELITIAN DAN PEMBAHASAN}

\section{Hasil Penelitian}

Budi Utomo merupakan sebuah organisasi pelajar yang didirikan oleh Dr.Sutomo dan para mahasiswa STOVIA (School tot Opleiding voor Inlandsche Arsten) yaitu Goenawan, Dr. Cipto Mangoenkeosoemo dan Soeraji serta R.T Ario Tirtokusumo, yang didirikan di Jakarta pada 20
Mei 1908. Organisasi ini bersifat sosial, ekonomi, dan kebudayaan.

Dalam karyanya Akira Nagazumi menegaskan bahwa berdirinya Budi Utomo tak bisa lepas dari peran Dr. Wahidin Sudirohusodo. Walaupun bukan pendiri Budi Utomo, namun beliaulah yang telah menginspirasi Dr. Sutomo dan kawan-kawan untuk mendirikan organisasi pergerakan nasional ini. Dr.Wahidin Sudirohusodo sendiri adalah seorang alumni STOVIA yang sering berkeliling di kota-kota besar di Pulau Jawa untuk mengkampanyekan gagasannya mengenai bantuan dana bagi pelajarpelajar pribumi berprestasi yang tidak mampu melanjutkan sekolah. Gagasan ini akhirnya beliau kemukakan kepada pelajar-pelajar STOVIA di Jakarta, dan ternyata mereka menyambut baik gagasan mengenai organisasi tersebut dan dari sinilah awal perkembangan menuju keharmonisan bagi orang Jawa dan Madura. Gagasan ini pula yang menginspirasi para mahasiswa dalam perkuliahan Strategi Pembelajaran Sejarah dengan membuat suatu Quotes yang mampu menggugah kesadaran nasional para pemuda.

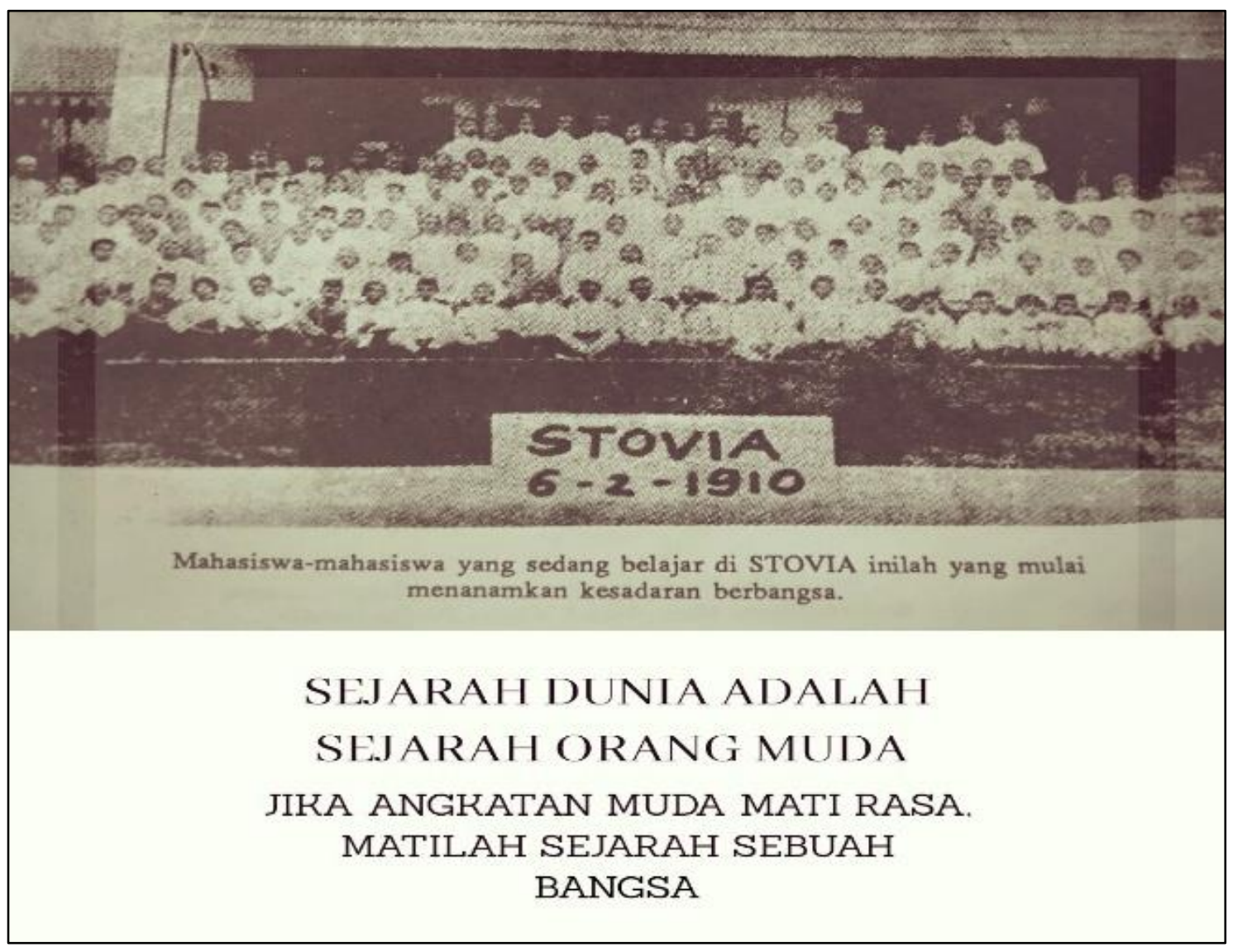

Karya Nurul Yuliani; mahasiswa pendidikan sejarah (FKIP USD) angkatan 2017 
Budi utomo sebagai organisasi pelajar yang baru muncul ini, secara samar-samar merumuskan tujuannya untuk kemajuan Hindia, dimana yang jangkauan gerak semulanya hanya terbatas pada Pulau Jawa dan Madura yang kemudian diperluas untuk penduduk Hindia seluruhnya dengan tidak memperhatikan perbedaan keturunan, jenis kelamin dan agama. Namun dalam perkembangannya terdapat perdebatan mengenai tujuan Budi Utomo, dimana Dr. Cipto Mangunkusumo yang bercorak politik dan radikal, Dr. Radjiman Wedyodiningrat yang cenderung kurang memperhatikan keduniawian serta Tirtokusumo (Bupati Karanganyar) yang lebih banyak memperhatikan reaksi dari pemerintah kolonial dari pada memperhatikan reaksi dari penduduk pribumi(Soedarto, 1979:26).

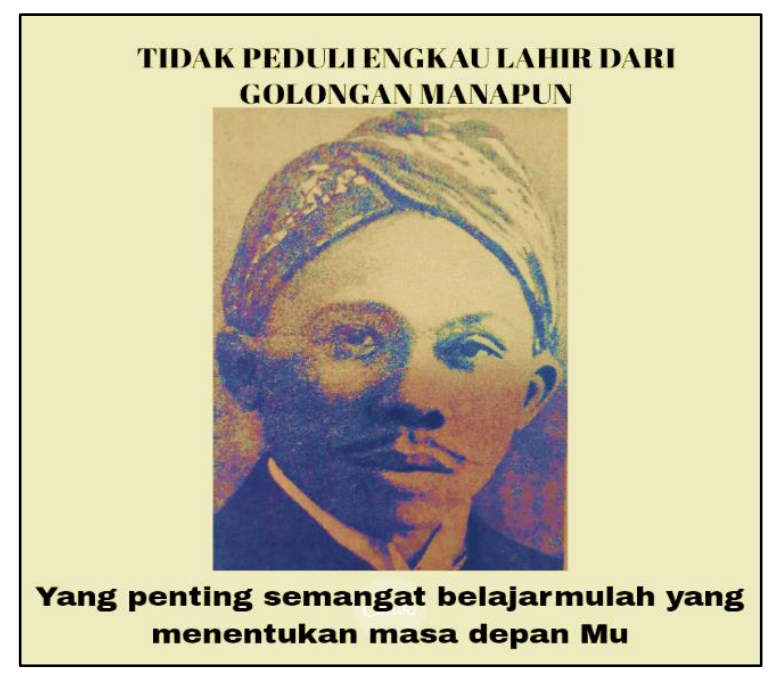

Karya Prayer Yosua Ari Tonang; mahasiswa pendidikan sejarah (FKIP USD) angkatan 2017

Setelah perdebatan yang panjang, maka diputuskan bahwa jangkauan gerak Budi Utomo hanya terbatas pada penduduk Jawa dan Madura dan tidak akan melibatkan diri dalam kegiatan politik. Bidang kegiatan yang dipilihnya pendidikan dan budaya. Pengetahuan bahasa Belanda mendapat prioritas utama, karena tanpa bahasa itu seseorang tidak dapat mengharapakan kedudukan yang layak dalam jenjang kepegawaian kolonial. Dengan demikian Budi Utomo cenderung untuk memejukan pendidikan bagi golongan priyayi dari pada bagi penduduk pribumi pada umumnya. Slogan Budi Utomo berubah dari perjuangan untuk mempertahankan penghidupan menjadi kemajuan secara serasi. Hal ini menunjukkan pengaruh golongan tua yang moderat dan golongan priyayi yang lebih mengutamakan

(Poesponegoro;Notosusanto, 1984:178).

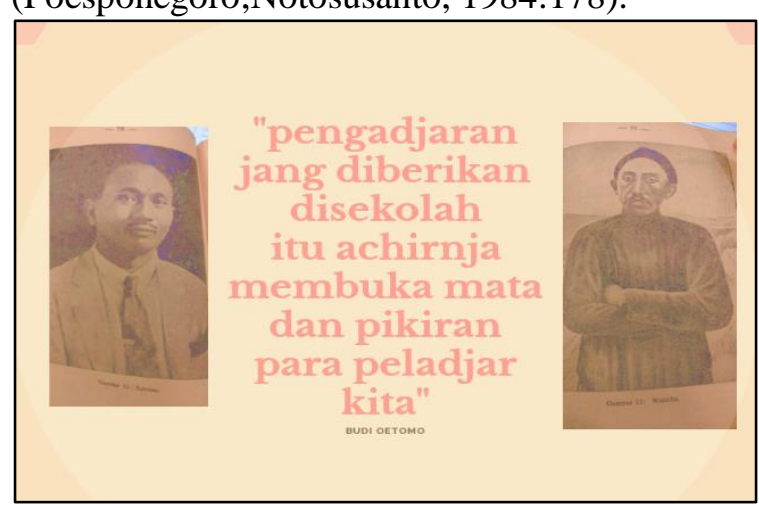

Karya Agung Kurniasthi dan Elisabeth; mahasiswa pendidikan sejarah t(FKIP USD) angkatan 2017

Pancaran eksistensi Budi Utomo di Indonesia dibuktikan dengan diadakannya konggresnya yang pertama di Yogyakarta pada tanggal 3-5 Oktober 1908. Dalam waktu singkat Budi Utomo mengalami perubahan orientasi. Kalau semula orientasinya terbatas pada kalangan priyayi maka menurut edaran yang dimuat dalam Bataviaasch Nieuwsblad tanggal 23 Juli 1908, Budi Utomo cabang Jakarta menekankan cara baru bagaimana memperbaiki kehidupan rakyat. Di dalam konggres tersebut menghasilkan beberapa keputusan,sebagai berikut :

1. Tidak mengadakan kegiatan politik.

2. Bidang utama adalah pendidikan dan kebudayaan.

3. Terbatas wilayah Jawa dan Madura.

4. Mengangkat Raden Adipati Tirtokusumo (Bupati Karanganyar) sebagai ketua Budi Utomo.

Semenjak dipimpin oleh Raden Adipati Tirtokoesoemo, banyak anggota baru Budi Utomo yang bergabung dari kalangan bangsawan dan pejabat kolonial, sehingga banyak anggota muda yang memilih untuk menyingkir. Di bawah kepengurusan generasi tua, kegiatan Budi Utomo yang awalnya terpusat di bidang pendidikan, sosial, dan budaya, akhirnya mulai bergeser di bidang politik. Strategi perjuangan Budi Utomo juga ikut berubah dari yang awalnya sangat menonjolkan sifat protonasionalisme menjadi lebih kooperatif dengan pemerintah kolonial belanda(Soedarto, 1978:26). 
Perkembangan selanjutnya merupakan periode yang paling lamban bagi Budi Utomo. Aktivitasnya hanya terbatas pada penerbitan majalah bulanan Goeroe Desa dan beberapa petisi, yang di buatnya kepada pemerintah berhubung dengan usaha meninggikan mutu sekolah menengah pertama. Tatkala kepemimpinan pengurus pusat makin melemah, maka cabang-cabang BU melakukan aktivitas sendiri yang tidak banyak hasilnya. Pemerintah yang mengawasi perkembangan Budi Utomo sejak berdirinya, dengan penuh perhatian dan harapan akhirnya menarik kesimpulan bahwa pengaruh Budi Utomo terhadap penduduk pribumi tidak begitu besar (Poesponegoro; Notosusanto, 1984:178).

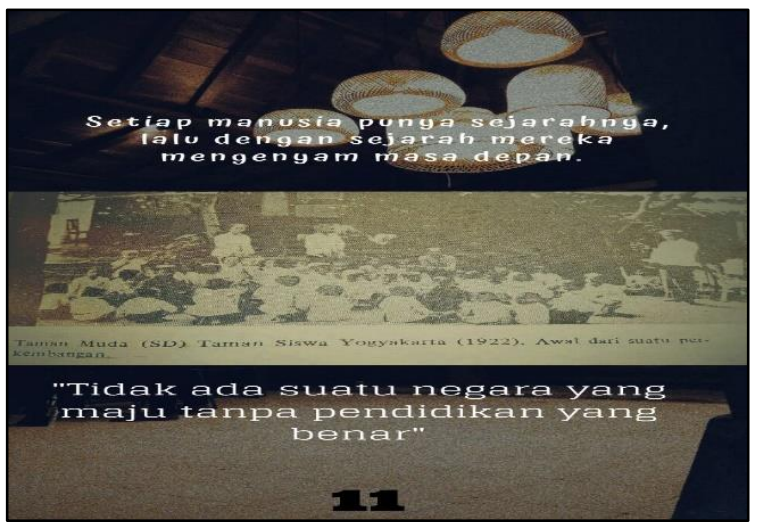

Karya Gabriel Pradipta, Rafael, Gunard; mahasiswa pendidikan sejarah (FKIP USD) angkatan 2017

Pada tahun 1912 terjadi pergantian pemimpin dari Tirtokusumo ke tangan Pangeran Noto Dirodjo yang berusaha dengan sepenuh tenaga mengejar ketinggalan. Dengan ketua yang baru itu, perkembangan Budi Utomo tidak begitu pesat lagi. Hasil-hasil yang pertama dicapainya, yaitu perbaikan pengajaran di daerah kesultanan dan kasunanan. Budi Utomo mendirikan organisasi Darmoworo. Tetapi hasilnya tidak begitu pesat. Dalam masa kepemimpinannya terdapat dua organisasi nasional lainnya yaitu syarekat Islam dan Indische Partij. Kedua partai tersebut merupakan unsur-unsur yang tidak puas terhadap Budi Utomo.

Budi Utomo menempuh cara dan menyesuaikan dengan situasi dan kondisi pada waktu itu, sehingga wajar jika Budi Utomo berorientasi pada kultural, bukan politik. Tindakan yang tepat ini berarti Budi Utomo tanggap terhadap politik kolonial yang sedang berlaku. Contohnya ialah bahwa pemerintah sudah memasang rambu Regeerings Reglement (RR) pasal 111 yang bertujuan membatasi hak untuk rapat dan berbicara, dengan perkataan lain adanya pembatasan hak berpolitik.

Selama RR masih berlaku maka kegiatan Budi Utomo hanya terbatas pada bidang sosiokultural. Ini merupakan bukti bahwa Budi Utomo selalu menyesuaikan diri dengan keadaan sehingga gerakan kultural lebih mewarnai kegiatan Budi Utomo pada fase awal. Kebudayaan sendiri dijunjung tinggi guna menghargai harkat diri agar mampu menghadapi kultur asing yang masuk. (Suhartono, 2001:32).

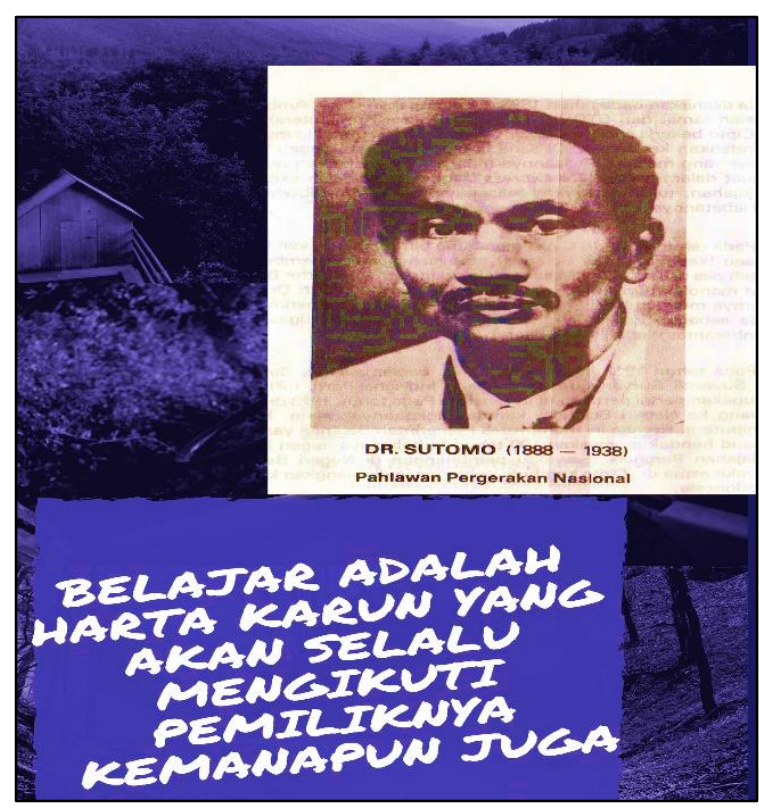

Karya Fr. Isak dan Aini ; mahasiswa pendidikan sejarah (FKIP USD) angkatan 2017

Pada dekade ketiga abad XX kondisikondisi sosio-politik makin matang dan Budi Utomo mulai mencari orientasi politik yang mantap dan mencari massa yang lebih luas. Kebijakan politik yang dilakukan oleh pemerintah kolonial, khususnya tekanan terhadap pergerakan nasional maka Budi Utomo mulai kehilangan wibawa, sehingga terjadilah perpisahan kelompok moderat dan radikal dalam Budi Utomo. Selain itu juga, karena Budi Utomo tidak pernah mendapat dukungan massa, kedudukannya secara politik kurang begitu penting, sehingga pada tahun 1935 organisasi ini resmi dibubarkan. (Ricklefs, 1998:251)

Tujuan organisasi Budi Utomo tidak maksimal karena banyak hal, yaitu :

1. Adanya kesulitan finansial. 
2. Adanya sikap Raden Adipati Tirtokusumo yang lebih memperhatikan kepentingan pemerintah kolonial dari pada rakyat.

3. Lebih memajukan pendidikan kaum priyayi dibanding rakyat jelata.

4. Keluarnya anggota dari gologan mahasiswa.

5. Bahasa Belanda lebih menjadi prioritas utama dibandingkan dengan Bahasa Indonesia.

Priyayi yang lebih mementingkan jabatan lebih kuat dibandingkan jiwa nasionalisnya.

\section{PENUTUP}

\section{Simpulan}

Pendidikan menjadi akar semangat kemajuan bangsa. Banyak generasi milenial yang tidak mengerti mengapa suatu kehidupan harus melalui pendidikan. Budi Utomo menggerakan semangat pemuda dan menyadarkan setiap pribadi bahwa satu-satunya jalan melawan penindasan dan kebodohan ialah pendidikan. Maka banyak pemuda diambil untuk memikirkan masa depan bangsa Indonesia. Semangat juang inilah yang mesti tertanam pada pemuda masa kini agar mau memikirkan masa depan dan berjuang untuk bangsa.

\section{DAFTAR PUSTAKA}

Akira nagazumi. (1989). Bangkitnya Nasionalisme Indonesia: Budi Utomo 1908-1918.Jakarta: PT Pustaka Utama Grafiti.

Blumberger, J. Th. Petrus. (1931). De Nationalistische Beweging In Nederlandsch-Indie, Haarlem, H.D. Tjeenk Willink \& Zoon N/V.

M.Harun Alrasyid. Zaman Bergerak: Analisis Historis tentang Awal Perjuangan Politik Indonesia Masa Kolonialisme 1912-1926, dalam Jurnal Madani, Vol 1, Mei 2006

Madjelis Luhur Persatuan Tamansiswa, Karja Ki Hadjar Dewantara. Yogyakarta: Madjelis Luhur Persatuan Tamansiswa, 1961.

Poesponegoro, M.D dan Notosusanto, N. (1984). Sejarah Nasional Indonesia V. Jakarta: Balai Pustaka.

Soedarto, dkk. (1979). Sejarah Kebangkitan Nasional Daerah Kalimantan Barat. Jakarta: Depdikbud.

Suhartono. (2001). Sejarah Pergerakan Nasional Dari Budi Utomo sampai
Proklamasi 1908-1945. Yogyakarta: Pustaka Pelajar

Sumardi,dkk. The Intelectual's Constribution In The National Movement of In Indonesian 1908-1928. Jurnal Historica, Universitas Negeri Jember (UNEJ), Vol.1, No 2, 2017. 
Jurnal Artefak:

History and Education, Vol.6 No.1 April 2019

Halaman | 6 